\title{
АНАЛІЗ СТРЕСОСТІЙКОСТІ СТУДЕНТІВ МОЛОДШИХ КУРСІВ ЗАКЛАДІВ ВИЩОЇ МЕДИЧНОЇ ОСВІТИ З РІЗНИМИ РІВНЯМИ ФІЗИЧНОГО ЗДОРОВ'Я В ДИНАМІЦІ НАВЧАЛЬНОГО ПРОЦЕСУ
}

\begin{abstract}
Анотація. У статті теоретично обгрунтовано наявність психологічного стресу у житті студента. Визначено рівень фізичного здоров’я здобувачів, який є основою їхніх функціональних резервів, і забезпечуе швидкий та успішний пристосувальний процес до стресора. Результати показують, що більшість студентів перебувае за межами «безпечного» рівня фізичного здоров'я. Проаналізовано стресостійкість 220 студентів першого курсу Вінницького національного медичного університету ім. М.І. Пирогова в залежності від інтенсивності інтелектуального навантаження протягом навчального року. Встановлено, що зі зниженням рівня фізичного здоров'я знижуеться і рівень стресостійкості досліджуваних. Також студенти з низьким та нижче середнього рівнем фізичного здоров'я гірше пристосовуються до максимального навчального стресу. В статті також запропоновано метод підвищення емоційної стійкості студентів-медиків в умовах навчального процесу.
\end{abstract}

Ключові слова: студенти, заклади вищої медичної освіти, рівень фізичного здоров’я, стресостійкість, психологічний стрес.

Tysevych Tatiana

National Pirogov Memorial Medical University

\section{ANALYSIS OF STRESS RESISTANCE OF STUDENTS JUNIOR COURSES INSTITUTIONS OF HIGHER MEDICAL EDUCATION WITH DIFFERENT LEVELS OF PHYSICAL HEALTH IN THE DYNAMICS OF THE EDUCATIONAL PROCESS}

Summary. Today, most people, especially young people, are under the influence of psychological stress. In the article theoretically substantiated the presence of psychological stress in a student's life. The constant flow of information helps to strengthen the mental activity of the body to absorb and process data. This can cause a violation of the psychological stability of the individual, causing psychological stress and overexertion. The main stressor of the student period is learning activities, namely: a large flow of information, daily control of the level of knowledge, modules and exams, conflicts with teachers and students, the need to organize extracurricular activities (self-training, life, leisure). The exam stress is one of the leading causes of mental stress in students, especially first-year students. The level of physical health of students is determined, which is the basis of their functional reserves and provides a fast and successful adaptation process to stressors. The results show that most students are outside the "safe" level of physical health, because they have medium, below average or low levels. Stress resistance is a property of the organism, which characterizes the degree of its adaptation to the influence of various factors and is determined not only by the level of development of psychological mechanisms, but also physiological. In the article there are three levels of stress resistance: high, medium, low. The stress resistance of 220 first-year students National Pirogov Memorial Medical University was analyzed depending on the intensity of intellectual load during the school year: in intersessional and session periods. It has been found that with a decrease the level of physical health, the level of stress resistance of students decreases. Also, students with low and below average levels of physical health are worse adapt to the maximum learning stress. However, it should be noted that boys did not have a low level of stress resistance in either in the intersessional or in the session period, in contrast to girls. The article also proposes method to increase the emotional stability and psychophysiological potential of medical students.

Keywords: students, institutions of higher medical education, level of physical health, stress resistance, psychological stress.

$\Pi$ остановка проблеми. Сучасне українське суспільство супроводжуе різноманіття небезпечних чинників - нестабільність соціально-економічних, політичних, екологічних процесів, в тому числі зростання темпу життя та підвищення вимог до нього. Постійний потік інформації сприяе посиленню психічної діяльності організму, щоб засвоїти та переробити дані. Це може бути причиною порушення психологічної стійкості особистості, викликаючи психологічне напруження та перенапруження.

Аналіз останніх досліджень та публікацій. Стрес $є$ складовою життя, у помірних дозах він надає життю смак і аромат (Г. Сельє, 1982).
Умовно можна поділити стрес на приемний і неприємний, корисний і шкідливий. Корисний стрес супроводжуеться позитивними переживаннями, перемогами тощо. Шкідливий стрес супроводжується негативними емоційними станами, та може бути причиною виникнення захворювань [1, с. 16]. Патогенний вплив надмірного стресу на здоров'я людини спричиняе розлади опорно-м'язового апарату (напруження м'язів, порушення іннервацї тканин, запалення в м'язах, суглобах, зв'язках), порушення обміну речовин (зникає або зростає потреба у їжі, надмірний потяг до солодкого), порушення психоемоцийної регуляції (розлади сну, нервозність, дратівливість, хронічна втома), дисфункції різних систем (серцево-судинної, травної, ендокринної тощо). 
Залежно від характеру зовнішніх впливів розрізняють стрес фрізіологічний і психологічний. Фізіологічний стрес - це негативний вплив на органи та тканини організму, характерною ознакою якого е біль. Психологічний стрес - це вплив на людину позитивних чи негативних емоцій та почуттів. Психологічний стрес в свою чергу поділяеться на інформаційний (інформаційні перевантаження) та емоційний (надмірні емоції, зміна поведінки) [2, с. $64 ; 3$, с. 7].

Основною умовою виникнення психологічного стресу е сприйняття людиною того чи іншого чинника як загрози (Р. Лазарус) [4, с. 10]. Таким чином прояв психологічного стресу в певній ситуації залежить не від об’ективних характеристик, а від суб'єктивних особливостей сприйняття i індивідуальних стереотипів, які вже склалися.

Психологічний стрес призводить до активації механізмів психофрізіологічної адаптації, робота якої, направлена на оптимізацію психофізіологічних ресурсів і збереження соматичного здоров'я. Тому наскільки успішно та швидко людина адаптуеться до стресора, залежить від адаптаційних ресурсів.

Слід зазначити, що не кожен вплив викликає стрес. Слабкі впливи не призводять до стресу, він виникае лише тоді, коли вплив чинника перевершуе звичайні пристосувальні можливості індивіда і організм змушений адаптуватися до нових умов.

На сьогодні більшість людей, особливо молодь, перебуває під впливом психологічного стресу.

Студентство - це період вікової кризи, який припадае переважно на пізню юність або ранню дорослість [5, с. 40]. Цей період характеризуеться оволодінням різними соціальними ролями дорослої людини, отриманням права вибору, набуття певної юридичної та економічної відповідальності, можливості включення в усі види соціальної активності (навіть державного рівня), здобуттям вищої освіти та опануванням професіею. Сферами життедіяльності студентів е професійне навчання, особистісне зростання та самоствердження, розвиток інтелектуального потенціалу, духовне збагачення, моральне, естетичне і dpiзичне самовдосконалення.

Особисті чинники або чинники навколишнього середовища, які призводять до дисбалансу фрізіологічних та психологічних фрункції організму називаються стресорами [6, с. 10].

Основним стресором студентського періоду є навчальна діяльність, а саме: великий інформаційний потік, щоденний контроль рівня знань, підсумки та екзамени, конфлікти з викладачами та студентами, необхідність організації позанавчальної діяльності (самопідготовки, побуту, дозвілля). Як показують дослідження Ю.В. Щербатих, екзаменаційний стрес займає одне з перших місць серед причин, що викликають психічну напругу в студентів, особливо, перших курсів [7, с. 76].

Під терміном «стресостійкість» дослідники розуміють емоційну стійкість, психологічну стійкість до стресу, стрес-резистентність, фрустраційну толерантність та ін. У психологічному словнику стресостійкість характеризуеться як певна сукупність особистісних якостей, які дозволяють людині переносити значні інтелек- туальні, вольові, емоційні навантаження (перенавантаження), обумовленні особливостями життедіяльності, без особливих шкідливих на-

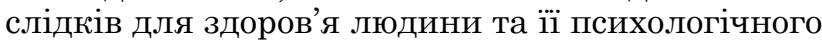
благополуччя. На думку В.О. Бодрова, стресостійкість - це інтегративна властивість людини, яка характеризуе ступінь їі адаптації до впливу екстремальних фракторів діяльності. Стійкість до стресу визначається рівнем розвитку психічних, фізіологічних та сощіальних механізмів регуляції поточного функціонального стану і поведінки в цих умовах [8].

Стресостійкість дозволяе студенту подолати негативні наслідки стресових ситуацій, зберегти себе від дезінтеграції та різноманітних розладів, створити основу для внутрішньої гармонії, високої працездатності, визначити успішність своєї професійної діяльності та зберегти власне здоров'я.

Загальновідомо, що пристосувальні процеси організму людини до дії різноманітних чинників є маркерами фізичного здоров'я. А рівень фрізичного здоров'я населення, в свою чергу, $е$ інтегральним показником розвитку країни, відображає її соціально-економічний та культурний потенціал. За даними Всесвітньої організації охорони здоров'я, фрізичне здоров'я людини на $50 \%$ залежить від способу життя, на 20\% - від впливу навколишнього середовища, на $20 \%$ - від спадковості та $10 \%$ складають доступність і якість медичної допомоги.

Виділення невирішених раніше частин загальної проблеми. Стрес - це психологічний стан, але реакції на цей стан проявляються і на фрізіологічному рівні, який залежить від рівня функціонування організму в цілому чи окремих систем. Основою функціональних резервів організму є фрізичне здоров'я. Однак, у вітчизняній літературі недостатньо висвітлено питання стосовно здатності студента чинити опір стресорам в залежність від рівня фізичного здоров'я.

Мета дослідження: визначити рівень стресостійкості студентів I курсу закладів вищої медичної освіти в міжсесійний і сесійний періоди та встановити її взаємозв'язок з рівнем фрізичного здоров'я.

Виклад основного матеріалу дослідження. Дослідження проводилося на базі Вінницького національного медичного університету, в якому взяли участь 230 студентів I курсу медичного профілю віком від 17 до 22 років. Всі студенти належали до групи "практично здорових» згідно з амбулаторними картками.

Оцінка рівня фізичного здоров'я проводилася за методикою кількісної експрес-оцінки рівня соматичного здоров'я (Г.Л. Апанасенко), яка включала в себе вимірювання антропометричних показників (зріст, маса тіла, життева ємність легень, артеріальний тиск систолічний і діастолічний, пульс) в спокої та функціональну проба Мартінета [9].

Для діагностики стресостійкості використали методику діагностики стану стресу (ДСС) К. Шрайнера. Згідно цієї методики виділяють три рівні стресостійкості: високий, середній, низький. Високий рівень стресостійкості вказуе на те, що студент досить стримано себе веде в різних стресових ситуаціях та контролюе свої емоції, 


\section{Розподіл рівня фізичного здоров'я за статтю (\%)}

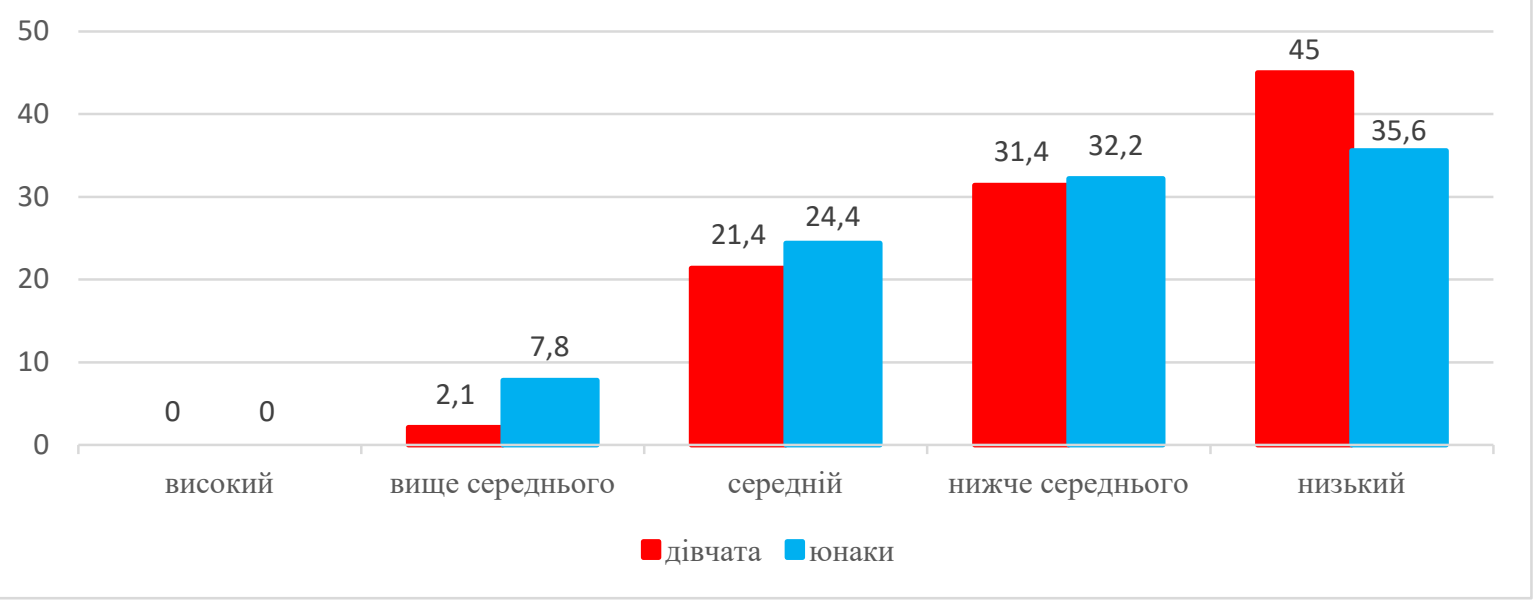

Рис. 1. Розподіл рівня фізичного здоров'я за статтю

він не дратується на інших і не налаштований звинувачувати себе; середній рівень стресостійкості характеризуеться втратою самоконтролю в певних ситуаціях, такі люди заводяться через дрібницю, а потім шкодують про це; низький рівень стресостійкості вказуе на те, що людина втомлена та виснажена, не вміє володіти своїми емоціями та потребує навиків саморегуляції в стресі [10, с. 115].

При вивченні рівня фрізичного здоров'я було встановлено, що з 230 студентів I курсу високий рівень фізичного здоров'я взагалі не реєструвався, вище середнього мали 10 чоловік, що становить 4,3\% від загальної кількості досліджуваних. До середнього рівня фрізичного здоров'я було віднесено $22,6 \%$, нижче середнього $31,7 \%$ та низького 41,3\% студентів. Розподіл рівня фрізичного здоров'я за статтю див. рис. 1.

Весь масив обстежених ми розділили в окремі групи дівчат (140 осіб) та юнаків (90 осіб). Юнаки та дівчата 3 рівнем фрізичного здоров'я вище середнього були виключені 3 дослідження через низьку репрезентативність вибірки. Решта склали групи з середнім (30 дівчат і 22 юнаків), нижче середнього (44 дівчат і 29 юнаків) та низьким (63 дівчат і 32 юнаки) рівнями фрізичного здоров'я. Стресостійкість студентів на I курсі навчання оцінювалась двічі - протягом навчального року (міжсесійний період) та під час літньої сесії (сесійний період).

Аналіз стресостійкості показав, що протягом I року навчання у більшості студентів 132 особи (60\%) була висока стресостійкість, 3 них 80 дівчат $(36,36 \%)$ та 52 юнаків (23,64\%). Середню стресостійкість мали 86 студентів (25\% дівчат і 14,1\% юнаків), а також у двох дівчат (0,9\%) відмічалася низька стесостійкість. Однак під час літньої сесії стресостійкість студентів-медиків знизилася високий іï рівень мали лише $21,36 \%$ студентів (23 дівчат і 24 юнаків), 78,64\% досліджуваних (114 дівчат і 59 юнаків) потребували самоконтролю в стресовій ситуації.

При розподілі студентів за рівнем фрізичного здоров'я (таблиця 1) вияснилося, що на I курсі в міжсесійний період більшість дівчат 3 середнім рівнем фрізичного здоров'я 83.3\% мали ви- соку стресостійкість, і по мірі зниження рівня фізичного здоров'я ця стресостійкість теж знижувалася, так 3 нижче середнього рівнем фізичного здоров'я складала $54,5 \% \quad\left(\mathrm{p}_{(\mathrm{Iн} / \mathrm{c}-\mathrm{c})}<0,05\right)$ i 3 низьким рівнем фізичного здоров'я $49,2 \%$ $\left(\mathrm{p}_{\text {(Ін-с) }}<0,01\right)$. В той же час середню стресостійкість мали $16,7 \%$ дівчат 3 середнім рівнем фрізичного здоров'я, 43,2\% $\left(\mathrm{p}_{(\mathrm{IH} / \mathrm{ccc})}<0,05\right) 3$ нижче середнього та $49,2 \%\left(\mathrm{p}_{(\text {Ін-с) }}<0,01\right)$ з низьким рівнями фрізичного здоров'я. Крім того, слід зазначити, що були дівчата, які потребували навиків саморегуляції в стресі - 2,3\% 3 нижче середнього та 1,6\% 3 низьким рівнями фрізичного здоров'я. При тих же умовах високо стресостійкими виявилися 77,3\% юнаків з середнім, 51,7\% з нижче середнього та $62,5 \%$ 3 низьким рівнями фізичного здоров'я. Середня стресостійкість відмічалася в $22,7 \%$ юнаків 3 середнім рівнем фрізичного здоров'я, 48,3\% 3 нижче середнього та $37,5 \%$ з низьким рівнями фрізичного здоров'я.

Сесійний період I курсу виявився емоційно напруженим для студентів, адже 63,3\% дівчат та 45,5\% юнаків з середнім рівнем фрізичного здоров'я потребували самоконтролю у стресовій ситуащії. I зі зниженням рівня фрізичного здоров'я кількість студентів, які мали середню стресостійкість збільшувалась, серед них були $88,6 \%\left(\mathrm{p}_{(\mathrm{IH} / \mathrm{c}-\mathrm{c})}<0,05\right)$ дівчат та $79,3 \%\left(\mathrm{p}_{(\mathrm{Iн} / \mathrm{c}-\mathrm{c})}<0,05\right)$ юнаків 3 нижче середнього і $84,1 \%(\mathrm{p}(\mathrm{IH}-\mathrm{c})<0,05)$ дівчат та $81,3 \%\left(\mathrm{p}_{(\mathrm{Iн-c)}}<0,01\right)$ юнаків 3 низьким рівнями фрізичного здоров'я. Стресостійкими були лише $36,7 \%$ дівчат та $54,5 \%$ юнаків з середнім, $9,1 \% \quad\left(\mathrm{p}_{(\mathrm{Iн} / \mathrm{c}-\mathrm{c})}<0,01\right)$ дівчат та $20,7 \% \quad\left(\mathrm{p}_{(\mathrm{IH} / \mathrm{c}-\mathrm{c})}<0,05\right)$ юнаків з нижче середнього і $12,7 \%\left(\mathrm{p}_{(\text {(н-с) }}<0,01\right)$ дівчат та $18,8 \%\left(\mathrm{p}_{(\mathrm{Iн-c)}}<0,01\right)$ юнаків 3 низьким рівнями фрізичного здоров'я.

Показники стану стресу серед студентів I курсу в міжсесійний та сесійний періоди показали, що висока стресостійкість зменшилася під час сесії у дівчат 3 середнім $\left(\mathrm{p}_{\text {(М-Ic)(C-Ic) }}<0,001\right)$, нижче середнього $\left(\mathrm{p}_{(\mathrm{M}-\mathrm{I} / \mathrm{c})(\mathrm{C}-\mathrm{Iн} / \mathrm{c})}<0,001\right)$ та низьким $\left(\mathrm{p}_{(\mathrm{M}-\mathrm{Iн)}(\mathrm{C}-\mathrm{Iн)}}<0,001\right)$ рівнями фрізичного здоров'я. В той же час як потреба самоконтролю дівчат в період сесії зросла $\left(\mathrm{p}_{(\mathrm{M}-\mathrm{Ic})(\mathrm{C}-\mathrm{Ic})}<0,001\right),\left(\mathrm{p}_{(\mathrm{M}-\mathrm{Iн} / \mathrm{c})(\mathrm{C}-\mathrm{Iн} / \mathrm{c})}<0,001\right)$, $\left(\mathrm{p}_{(\mathrm{M}-\mathrm{IH})(\mathrm{C}-\mathrm{Iн)}}<0,001\right)$. Серед юнаків I курсу достовірні відмінності між рівнями стресостійкості в різні 
Таблиця 1

Порівняння стресостійкості в юнаків і дівчат на I курсі навчання

в міжсесійний та сесійний періоди в залежності від рівня фізичного здоров'я (\%)

\begin{tabular}{|c|c|c|c|c|c|c|c|c|}
\hline \multirow{2}{*}{$\begin{array}{c}\text { Курс і рівень } \\
\text { фізичного здоров'я }\end{array}$} & \multicolumn{4}{|c|}{ Дівчата } & \multicolumn{4}{|c|}{ Юнаки } \\
\hline & $\mathbf{n}$ & 1 & 2 & 3 & $\mathbf{n}$ & 1 & 2 & 3 \\
\hline \multicolumn{9}{|c|}{ Міжсесійний період } \\
\hline I курс низький & 63 & 49,2 & 49,2 & 1,6 & 32 & 62,5 & 37,5 & 0 \\
\hline I курс нижче середн. & 44 & 54,5 & 43,2 & 2,3 & 29 & 51,7 & 48,3 & 0 \\
\hline I курс середній & 30 & 83,3 & 16,7 & 0 & 22 & 77,3 & 22,7 & 0 \\
\hline $\mathrm{p}_{(\mathrm{IH}-\mathrm{H} / \mathrm{c})}$ & & $\mathrm{p}>0,05$ & $\mathrm{p}>0,05$ & $\mathrm{p}>0,05$ & & $\mathrm{p}>0,05$ & $\mathrm{p}>0,05$ & $\mathrm{p}>0,05$ \\
\hline $\mathrm{p}_{(\mathrm{IH}-\mathrm{c})}$ & & $\mathrm{p}<0,01$ & $\mathrm{p}<0,01$ & $\mathrm{p}>0,05$ & & $\mathrm{p}>0,05$ & $\mathrm{p}>0,05$ & $\mathrm{p}>0,05$ \\
\hline $\mathrm{p}_{(\mathrm{IH} / \mathrm{c}-\mathrm{c})}$ & & $\mathrm{p}<0,05$ & $\mathrm{p}<0,05$ & $\mathrm{p}>0,05$ & & $\mathrm{p}>0,05 \mathrm{t}$ & $\mathrm{p}>0,05 \mathrm{t}$ & $\mathrm{p}>0,05$ \\
\hline \multicolumn{9}{|c|}{ Сесійний період } \\
\hline I курс низький & 63 & 12,7 & 84,1 & 3,2 & 32 & 18,8 & 81,3 & 0 \\
\hline I курс нижче середн. & 44 & 9,1 & 88,6 & 2,3 & 29 & 20,7 & 79,3 & 0 \\
\hline I курс середній & 30 & 36,7 & 63,3 & 0 & 22 & 54,5 & 45,5 & 0 \\
\hline $\mathrm{p}_{(\mathrm{IH}-\mathrm{H} / \mathrm{c})}$ & & $\mathrm{p}>0,05$ & $p>0,05$ & $p>0,05$ & & $p>0,05$ & $p>0,05$ & $\mathrm{p}>0,05$ \\
\hline $\mathrm{p}_{(\mathrm{IH}-\mathrm{c})}$ & & $\mathrm{p}<0,01$ & $\mathrm{p}<0,05$ & $\mathrm{p}>0,05$ & & $\mathrm{p}<0,01$ & $\mathrm{p}<0,01$ & $\mathrm{p}>0,05$ \\
\hline $\mathrm{p}_{(\mathrm{IH} / \mathrm{c}-\mathrm{c})}$ & & $\mathrm{p}<0,01$ & $\mathrm{p}<0,05$ & $\mathrm{p}>0,05$ & & $\mathrm{p}<0,05$ & $\mathrm{p}<0,05$ & $\mathrm{p}>0,05$ \\
\hline $\mathrm{p}_{(\mathrm{M} \text {-IH) (C-IH) }}$ & & $\mathrm{p}<0,001$ & $\mathrm{p}<0,001$ & $\mathrm{p}>0,05$ & & $\mathrm{p}<0,001$ & $\mathrm{p}<0,001$ & $\mathrm{p}>0,05$ \\
\hline $\mathrm{p}_{(\mathrm{M}-\mathrm{IH} / \mathrm{C})(\mathrm{C}-\mathrm{IH} / \mathrm{c})}$ & & $\mathrm{p}<0,001$ & $\mathrm{p}<0,001$ & $\mathrm{p}>0,05$ & & $\mathrm{p}<0,05$ & $\mathrm{p}<0,05$ & $\mathrm{p}>0,05$ \\
\hline $\mathrm{p}_{(\mathrm{M}-\mathrm{Ic})(\mathrm{C}-\mathrm{Ic})}$ & & $\mathrm{p}<0,001$ & $\mathrm{p}<0,001$ & $\mathrm{p}>0,05$ & & $\mathrm{p}>0,05$ & $p>0,05$ & $\mathrm{p}>0,05$ \\
\hline
\end{tabular}

Примітки: 1 - висока стресостійкість; 2 - середня стресостійкість; 3 - низька стресостійкість; р $_{\text {(І-с) }}-$ достовірність відмінностей між відповідними показниками у дівчат або юнаків із низьким і середнім фрізичним здоров'ям на I курсі; $\mathrm{p}_{(\text {(н/с-с) }}-$ достовірність відмінностей між відповідними показниками у дівчат або юнаків із нижче середнього та середнім фрізичним здоров'ям на I курсі; $p_{(\mathrm{M}-\mathrm{Iн)}(\mathrm{C}-\mathrm{Iн)}}$ - достовірність відмінностей між відповідними показниками в міжсесійний та сесійний періоди на I курсі у дівчат або юнаків із низьким фізичним здоров'ям; $\mathrm{p}_{(\mathrm{M}-\mathrm{Iн} / \mathrm{c})\left(\mathrm{C}-\mathrm{Iн}_{\mathrm{c}}\right)}-$ достовірність відмінностей між відповідними показниками в

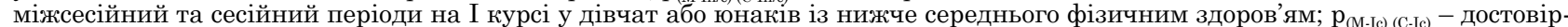
ність відмінностей між відповідними показниками в міжсесійний та сесійний періоди на I курсі у дівчат або юнаків із середнім фізичним здоров'ям; $\mathrm{p}_{(\text {(н-н/c) }}-$ достовірність відмінностей між відповідними показниками у дівчат або юнаків із низьким і нижче середнього фізичним здоров'ям на I курсі; $\mathrm{t}$ - тенденція відмінностей між відповідними показниками.

періоди (міжсесійний та сесійний) теж відмічалися $\left(\mathrm{p}_{(\mathrm{M}-\mathrm{IH} / \mathrm{c})\left(\mathrm{C}-\mathrm{IH}_{\mathrm{c}}\right)}<0,05\right),\left(\mathrm{p}_{(\mathrm{M}-\mathrm{IH})\left(\mathrm{C}-\mathrm{IH}_{\mathrm{H}}\right)}<0,001\right)$.

Також варто відзначити, що юнаки I курсу не проявляли низьку стресостійкість як в міжсесійний, так і сесійний періоди.

Достовірної різниці між стресостійкістю дівчат та юнаків на I курсі в міжсесійний і сесійний періоди не було (p>0,05).

Обговорення результатів. В результаті нашого дослідження бачимо, що високий рівень фрізичного здоров'я не реєструвався серед студентів взагалі, вище середнього - лише в незначної кількості досліджуваних (10 осіб). А саме високий та вище середнього рівні фізичного здоров'я вважаються «безпечними» [9]. В той же час переважав нижче середнього та низький рівні фрізичного здоров'я. Також бачимо залежність між рівнем стресостійкості та рівнем фрізичного здоров'я, чим нижчий рівень фрізичного здоров'я, тим нижча стресостійкість. Здача іспитів теж негативно відображалася на стресостійкості, знижуючи ï ( $<<0,001)$, особливо у студентів з низьким та нижче середнього рівнем фрізичного здоров'я. Тобто, екзаменаційний стрес $є$ причиною психологічної напруги, що вибиває студента з рівноваги.

Висновки. Отримані дані дають можливість стверджувати, що студенти дуже чутливі до дії різних стресогенних фракторів і схильні втрачати контроль над своїми емоціями при підвищенні психологічного навантаження. Занепокоєння викликає і той фракт, що більшість студентів перебувають за межами «безпечного» рівня фрізичного здоров'я. Зі зниженням рівня фрізичного здоров'я досліджуваних знижувалася стійкість до стресової ситуації.

Важливим напрямком подальшого розвитку теми є розробка психокорекційної програми для подолання наслідків негативних емощійних станів та підвищити психофрізіологічний потенціал організму. Оскільки психологічний стан безпосередньо залежить від думок, важливо контролювати своє відношення до життевих ситуацій. Щоб протистояти стресам, студент має перевести свою енергію в позитивну фрорму діяльності, займатись тим, що дає можливість зняти емоційну напругу.

\section{Список літератури:}

1. Наугольник Л.Б. Психологія стресу : підручник. Львів : Львівський державний університет внутрішніх справ, 2015. 324 с.

2. Пляка Л.В., Кайдалова Л.Г., Шаповалова В.С. Фізична культура та психофізіологічний тренінг : навчальний посібник. Харків : Нфау, 2018. 108 с.

3. Злепко М., Мінцер О.П., Сергеєва В.В., Азархов О.Ю., Костішин С.В. Сучасні методи і засоби для визначення і діагностування емоційного стресу : монографія / за заг. ред. О.П. Мінцера. Вінниця : ВНТУ, 2010.228 с.

4. Карташова К.С. Психология стресса : учеб.-метод. пособие. Красноярск : Сиб. федер. ун-т, 2012. 35 с.

5. Подоляк Л.Г., Юрченко В.І. Психологія вищої школи : Навчальний посібник для магістрантів і аспірантів. Київ : ТОВ “Філ-студія”, 2006. 320 с. 
6. Булах В.П. Стрес та його вплив на організм людини. Медсестринство. 2014. № 3. С. 10-15.

7. Щербатых Ю.В. Психология стресса и методы коррекции. Санкт-Петербург : Питер, 2008. 256 с.

8. Бодров В.А. Психологический стресс: развитие и преодоление. Москва : Пер Сэ, 2006. 528 с.

9. Апанасенко Г.Л., Попова Л.О. Медицинская Валеология. Київ : «Здоров’я», 1998. 248 с.

10. Габдреева Г.Ш., Прохоров А.О. Практикум по психологии состояний : Учебное пособие / Под ред. профр. А.О. Прохорова. Санкт-Петербург : Речь, 2004. 480 с.

\section{References:}

1. Nauholnyk L.B. (2015) Psykholohiia stresu: pidruchnyk. Lviv: Lvivskyi derzhavnyi universytet vnutrishnikh sprav, $324 \mathrm{p}$.

2. Pliaka L.V., Kaidalova L.H., Shapovalova V.S. (2018) Fizychna kultura ta psykhofiziolohichnyi treninh: navchalnyi posibnyk. Kharkiv: Nfau, 108 p.

3. Zlepko M., Mintser O.P., Sierhieieva V.V., Azarkhov O.Iu., Kostishyn S.V. (2010) Suchasni metody i zasoby dlia vyznachennia i diahnostuvannia emotsiinoho stresu: monohrafiia / za zah. red. O.P. Mintsera. Vinnytsia: VNTU, 228 p.

4. Kartashova K.S. (2012) Psykholohyia stressa: ucheb.-metod. posobye. Krasnoiarsk: Syb. feder. un-t, 35 p.

5. Podoliak L.H., Yurchenko V.I. (2006) Psykholohiia vyshchoi shkoly: Navchalnyi posibnyk dlia mahistrantiv i aspirantiv. Kyiv: TOV "Fil-studiia", 320 p.

6. Bulakh V.P. (2014) Stres ta yoho vplyv na orhanizm liudyny. Medsestrynstvo, no. 3, pp. 10-15.

7. Shcherbatykh Yu.V. (2008) Psykholohyia stressa y metody korrektsyy. Sankt-Peterburh: Pyter, 256 p.

8. Bodrov V.A. (2006) Psykholohycheskyi stress: razvytye y preodolenye. Moskva: Per Se, 528 p.

9. Apanasenko H.L., Popova L.O. (1998) Medytsynskaia Valeolohyia. Kyiv: «Zdorovia», 248 p.

10. Habdreeva H.Sh., Prokhorov A.O. (2004) Praktykum po psykholohyy sostoianyi: Uchebnoe posobye / Pod red. prof. A.O. Prokhorova. Sankt-Peterburh: Rech, 480 p. 